\title{
Liberal vs. Liberating Empowerment: A Latin American Feminist Perspective on Conceptualising Women's Empowerment ${ }^{1}$
}

\author{
Cecília M.B. Sardenberg
}

\begin{abstract}
1 Introduction
Since the early 1980s, feminists in Latin America have engaged in a range of programmes and activities aimed at promoting women's

empowerment, but have yet to produce frameworks to analyse this process at work. Tracing and reflecting upon the impressive advancements of feminist activism throughout the region has been a major focus for feminist analysis (Sternbach et al. 1992; Lavrin 1998). However, little thinking has gone into depicting how the flow of power/empowerment travels between individuals, groups and institutions, and thus towards linking gains at the macroinstitutional level with real changes in the everyday lives of women in different social contexts. Feminist thinking in the region still lacks concerted analysis of the linkages and discontinuities between individual agency, collective action and structural transformation, and how they operate in the process of women's empowerment and the eradication of patriarchal domination
\end{abstract}

Although 'empowerment' ('empoderamento') is a term considered new and foreign in Brazil, it has come to be as widely used and to carry as many different meanings as in English. This constitutes a major difficulty in working with this concept. As Srilatha Batliwala notes: 'It is one of the most loosely used terms in the development lexicon, meaning different things to different people - or, more dangerously, all things to all people' (1994: 1). As a consequence, there is a lot of mistrust in relation to empowerment on the part of Latin American feminists, as the term has been appropriated by mainstream organisations and by governments to legitimise policies and practices that, from a feminist perspective, are far from empowering for women. The notion of empowerment that has been propagated by mainstream development agencies and organisations differs considerably from its original meaning in feminist thinking. There are ambivalences, contradictions and paradoxes in the uses of the concept, as it is often used as a substitute to integration, participation, identity, development and planning, and hardly ever in reference to its emancipating origins (León 1997). In this article, I reflect on different ways of defining and conceiving women's empowerment from a Latin American feminist perspective.

\section{Feminism, power and empowerment} Teresa de Lauretis argues that 'there is no real boundary between feminism and what is external to it; no boundary separates or insulates feminism from other social practices or makes it impervious to the institutions of civil society' (1986: 4). Just as feministcoined concepts, such as 'gender' for instance, have been appropriated and re-signified in development discourse (Cornwall et al. 2007), so too development agendas and concepts have permeated feminist thinking about women's empowerment, making it difficult to disentangle the two.

Nevertheless, I argue that it is possible to distinguish two basic approaches in conceptualising women's empowerment. The first, which I will identify as the 'liberal empowerment' approach, regards women's empowerment as an instrument for development 
priorities, be they eradicating poverty or building democracy. Consistent with liberal ideals, the focus is on individual growth, but in an atomistic perspective, that is, on the notion of the rational action of social actors based on individual interests (Romano 2002). It is an approach that de-politicises the process of empowerment by taking power out of the equation. Instead, the focus is on technical and instrumental aspects that can supposedly be 'taught' in special training courses, for example.

In contrast, in the other approach - which I will call 'liberating empowerment' - power relations are the central issue. Women's empowerment is regarded as both on 'intrinsic grounds' (Kabeer 1999), as the process by which women attain autonomy and selfdetermination, as well as an instrument for the eradication of patriarchy, a means and an end in itself. Thus, although feminists also aspire to end poverty, wars, and build democratic states, in this feminist perspective the major objective of women's empowerment is to question, destabilise and, eventually, transform the gender order of patriarchal domination. Such an approach is consistent with a focus on women's organising, on collective action, though not disregarding the importance of the empowerment of women at a personal level.

Power is central to any conceptualisations of empowerment, and is at the very root of the term itself. Understandings of power and empowerment come from very different movements and traditions, being appropriated and re-signified by agencies and organisations that do not necessarily take the interests of these movements to heart (Oxaal and Baden 1997: 1). Besides, even within these different movements and traditions, the notions of power that underpin approaches and actions have changed significantly over time. For the purposes of this article perhaps one of the most useful understandings of power is the notion of 'power as empowerment' as recognised by Amy Allen (2005, 1999), one which she argues has developed as a result of the shortcomings of the 'power as resource' and 'power as domination' approaches in dealing with the power women are able to exercise even in a society dominated by a patriarchal order. In her words:

Feminists who conceptualize power as empowerment do of course acknowledge that, in patriarchal societies, men are in a position of dominance over women; but they choose to focus on a different understanding of power: power as the ability to empower and transform oneself, others, and the world. (Allen 1999: 18)

This view of empowerment is as a process by which people begin 'making decisions on matters which are important in their lives and being able to carry them out' (Mosedale 2005: 244). Feminists who conceptualise empowerment in this way argue that to be empowered 'one must have been disempowered' as women have as a group, and that 'empowerment cannot be bestowed by a third party', although it is possible to act as 'facilitator' of this process. Indeed, Srilatha Batliwala proposes that women's empowerment involves challenging patriarchal relations, which in turn requires that women first 'recognize the ideology that legitimizes male domination and understand how it perpetuates their oppression' (1994: 131). She further notes that this process of change does not necessarily 'begin spontaneously from the condition of subjugation'; it must be 'externally induced'. As she claims: 'Women must be convinced of their innate right to equality, dignity and justice' (Batliwala 1994: 132). Women's organisations play a fundamental role in bringing women together for their mutual empowerment.

Along with other feminists from the South (Léon 2001, for example), Batliwala claims that the concept of 'empowerment' thus conceived is a contribution from so-called 'Third World' feminists. More specifically, they see it as emerging as part of the debates and critiques of 'Third World' feminists and their attempts to articulate feminist thinking with the principles of popular education (Batliwala 1994). They also recognise the contribution of Gramsci's thoughts, particularly in relation to the importance of devising participatory mechanisms for the construction of more equitable and non-exploitative institutions. Yet, other feminists from the South (for instance, Bruera and González 2006: 69) suggest that the term was first used in the 1960s in the Civil Rights Movement in the United States, before being appropriated by feminists in the 1980s. 'Liberating' empowerment is also in line with the basic notions of the consciousness-raising groups of Second Wave Western feminisms, which started in the mid-1960s, providing form and content to the politicalpedagogical work developed by popular educators (Sardenberg 2005). 
Although the concept of empowerment has these roots, feminists started to use it actively only in the mid-1980s (Batliwala 1994). A particularly significant document was published in 1987 by DAWN (Development Alternatives for a New Era), Development, Crisis, and Alternative Visions by Gita Sen and Caren Grown, which was distributed by DAWN at workshops in the NGO Forum in Nairobi that was held during the Third World Conference on Women in 1985, in which close to 15,000 women participated. Sen and Grown formulated alternative proposals for change, bringing forth a vision of women's empowerment based on collective action. They stressed that the road toward women's empowerment had to be paved through structural transformation, through actions that promoted radical changes in the institutions of patriarchal domination. They emphasised that women's empowerment must be thought and acted upon not only in terms of gender inequalities, but also in terms of inequalities of class, race, ethnicity and other social determinants among women, as well as of the unequal position of North and South in the global arena.

Yet while the concept of 'empowerment' came to be taken up by feminists seeking to bring about more equitable development, it also lent itself to appropriation - or indeed misappropriation (Pereira, this IDS Bulletin) - by the development establishment. Indeed, in a provocative article, Ann Ferguson (2004) asks 'can development create empowerment and women's liberation?' And she observes that 'as a general goal, empowerment has been described as a political and a material process which increases individual and group power, self-reliance and strength' (2004: 1). However, she argues, 'there are two ways to define empowerment'. The first, associated here with 'liberal empowerment', defines empowerment as a process that individuals engage in to have access to resources so as to achieve outcomes in their self-interest. In this perspective, Ferguson emphasises, it seems that 'economic, legal and personal changes would be sufficient for individuals to become empowered, and such a process does not require the political organization of collectives in which such individuals are located.'

In Ferguson's view, the other way of thinking about empowerment, 'more influenced by empowerment as a goal of radical social movements, emphasizes the increased material and personal power that comes about when groups of people organize themselves to challenge the status quo through some kind of self-organization of the group' (2004: 1). This understanding of empowerment corresponds to what is regarded in this article as 'liberating empowerment', a perspective that is shared by most Latin American feminists who address issues of power/empowerment.

In what follows, I will examine 'liberal' and 'liberating' empowerment in turn, and look at their implications for feminist praxis.

\section{Liberal empowerment}

Liberal empowerment has its origins in liberalism, but also in liberal feminism's claim for equality and equal opportunities for women. ${ }^{2}$ While we may all agree with this claim for equality, it must be remembered that liberalism is not only associated with a political theory centred on notions of individual liberty, individual rights, and equal opportunity but also with neoclassical economics. It is the application of these economic theories in neoliberalism that has produced views and policies regarding the demands of the market for structural adjustment, privatisation, downsizing of the state and all of its consequences, which have been so vigorously criticised by Latin American and other feminists from the South.

Liberal feminist thinking has characteristically underlined much of development discourse and practice, particularly as espoused by bilateral agencies. Liberal feminist critiques of mainstream development led to the development of what came to be known as the WID approach, 'Women in Development' (Kabeer 1994; Razavi and Miller 1995) This approach sought to extend equal opportunities in development for women, by overcoming these social and cultural barriers through reform and providing equal access to women in education and training. However, it ignored the structures of patriarchal dominance that underlined inequalities between women and men, as well as class, race, ethnicity and other social determinants responsible for the inequalities among women. Nor did it question the underlying assumptions of the model of development into which it deemed to integrate women. 'It was not the mainstream model of modernization that was under attack, but the fact that women had not benefited from it' (Kabeer 1994: 20). 
During the United Nations Decade for Women (1976-85), feminist and women's movements emerged throughout the world, independently of WID efforts. They gained strength in the South through women organising at the grassroots level around a number of different issues, but having as their ultimate goal the empowerment of women, even if not spelled out precisely in these terms. Thus, it was not surprising that the critique of the WID approach came most strongly from feminists from the South, as formulated in the document (Sen and Grown 1987). This critique built on new developments in feminist theorising in the North, which departed fundamentally from liberal feminist thinking and emphasised the social construction of gender and the intersectionality of gender, race, and class. By 1995, when the Fourth World Conference on Women took place in Beijing, a new development discourse for women was being formulated, influenced by the development of an alternative approach, which came to be termed Gender and Development, or GAD. This approach emphasised power relations and structural inequalities, rooting analysis and action in conceptualising gender relations as socially constituted relations between women and men.

The focus shifted from integrating women into development to addressing issues of women's subordination through a focus on transforming gender relations (Razavi and Miller 1995). The Beijing Platform of Action, approved during the Fourth World Conference, incorporated this new perspective, as well as a discourse on women's empowerment. This had a widespread effect on the development 'machinery', as bilateral agencies and other organisations were to follow the adoption of this new term. By 2005, for example, 'more than 1,800 projects in the World Bank's lending portfolio mentioned empowerment in their project documentation' (Alsop et al. 2006: 1). Alsop et al. define empowerment as 'the process of enhancing an individual's or [a] group's capacity to make purposive choices and to transform those choices into desired actions and outcomes' (2006: 1). As I go on to discuss, this way of framing empowerment neglects fundamental questions of power.

Zabala (2006) shows the profound structural limits to the World Bank pursuing gender equity and women's empowerment in their projects. She contends:

These structural limits have two aspects that can be differentiated. On the one hand, the economistic vision promoted by the institution, that constitutes the nuclei of its theoretical thinking, does not favour these objectives and, on the other hand, its internal organisation and functioning is equally unfavourable. The existence of these structural limitations mark the possibilities and incoherences presented by the institution in working with gender issues. (2006: 31, my translation from the original in Spanish)

Of course, concepts and approaches cannot be easily transplanted from one conceptual framework into another that is radically different from the original one without suffering semantic changes. Without a significant change in their sustaining models, therefore, development agencies merely adopt the term 'empowerment' and not the approach it originally entailed. Transplanted into the liberal framework of modernisation theory, the notion of empowerment elaborated by feminists from the South could not survive as a transformative, revolutionary concept. Instead, what is observed is its use in a process of transformism, as explained by Jorge Romano:

... the empowerment evoked by banks and multilateral and bilateral development agencies, by different governments, and also by NGOs, has often been used primarily as an instrument of legitimation for them to continue doing, in essence, what they have always done. But now with a new name: empowerment. Or to control, within the parameters they themselves established, the potential of change originally impressed in these innovating categories and proposals. A typical situation of transformism (gattopardismo): to appropriate and distort the new, to guarantee the continuity of dominant practices. Adapting to the new times, changing 'everything' so as to change nothing.

(Romano 2002: 10, my translation from the original in Portuguese)

Despite emerging in feminist thinking as a critique of liberal notions of power, the concept of empowerment has been appropriated in this fashion in development discourse, legitimising practices that have little to do with the original concept developed by feminists from the South.

Analysing this appropriation of empowerment from a Foucauldian perspective, Ferguson argues that this 
implies the creation of a new development rationality. As she observes, it is no longer 'acceptable to describe the Third World clients/recipients of the training or enabling practices called empowerment practices as "illiterate", "disenfranchised", "backward" or "exploited".' To the contrary, it is now important to describe them as: "rational economic agents", "global citizens", potential "entrepreneurs"'. Development should then 'empower' them so that they can 'act as good entrepreneurs, wage earners, and consumers, that is, as proper "subjects/objects" of development' (2004: 7).

Obviously, this notion of 'liberal' empowerment actually fosters 'empowerment without power' in that it gives no space for changes in the existing power relations, nor in the structures of domination that are responsible for exclusion, poverty and disempowerment in the first place (Romano 2002) This results in diluted empowerment (or 'decaff' empowerment), as in the World Bank approach, which focuses on access to information, inclusion and participation, accountability and local organisational capacity, but does not discuss why some groups are excluded and do not have access to information, thus ignoring the structures of power that underscore the observed situation of exclusion and 'disempowerment' in the first place.

A consequence of ignoring these structures is to be found in the notion, held by liberal empowerment approaches, that empowerment is essentially a 'neutral' process, or that it is possible to have 'empowerment without conflicts'. This is based on the view that empowerment is an 'apolitical' process, or that the redistribution of resources can proceed without conflicts, or that the emerging conflicts can be 'technically resolved'. An example of this view is to be found in the 'harmonic model of partnership' that creates and maintains an illusion of consensus amongst stakeholders, and which is an important part of the World Bank hegemonic project (see Brock et al. 2001: 21). However, empowerment is not a technique to achieve progress without conflicts. If empowerment means changes in relations of domination, it cannot be neutral - it will engender conflict.

Moreover, empowerment is conceptualised in liberal empowerment as a ' 'gift', or as something that can be 'donated' or 'distributed'. This emerges from the major focus being on greater access to external resources, goods and services as a means of empowerment, rather than on the process of group organising and the building of self-esteem and trust as part of this process. This is an omission that also comes from a narrow view of participation. The tendency is thus to view empowerment as a technique to learn in special courses. The social and political dimensions of empowerment become reduced to technical and instrumental questions, as 'methodologies for empowerment', as kits one can buy and sell. It is no longer based on the exchange of experiences and the collective reflection upon them for change.

Jorge Romano's (2002) critique of this notion of empowerment calls attention to the problem of the over-politicisation and atomisation of empowerment, two distinct, actually opposite tendencies, but that present equally dangerous risks in the popularisation and generalisation of empowerment. In the first case, there is an overemphasis on the collective aspects of empowerment, with neglect of the individual elements. In the latter cases, the atomisation of empowerment, characteristic of liberal empowerment perspectives, are the tendencies to depoliticisation, fragmentation, and atomisation of situations of domination, created by the advancement of neoliberalism and the over-valorisation of individuality.

Indeed, as a rule, the kind of empowerment promoted by bilateral agencies and development banks is based on a notion of the rational action of actors towards individual interests. The focus is on changing individuals, even when working on group organising. This is not to say that the individual is not important. To the contrary, even when changes in the consciousness of domination are catalysed in group processes, it is always a personal and individual experience. However, as León (2001: 97) observes, it is necessary to distinguish this notion from an individualist view of the process:

One of the fundamental contradictions in the uses of the term 'empowerment' is expressed in the debate between individual and collective empowerment. For those who use the concept in the individual perspective, emphasising cognitive processes, empowerment is circumscribed to the meaning that individuals confer to themselves. It takes the sense of individual control, self-control. It is 'doing things by oneself', 'achieving success without the help of others'. This is an individualist view that gives priority to independent and 
autonomous actors, with a sense of self-control, and that ignores the links between power structures and everyday practises of individuals and groups, besides disconnecting people from the wider social, political and historical contexts, and of what solidarity, cooperation and being concerned for the other represent.

(My translation from the original in Spanish).

Despite these shortcomings, a number of projects and programmes in Latin America claim that they have been successful in 'empowering' women. For example, a study of NGOs working with poor women in Belo Horizonte, Brazil, shows that by offering training in professional skills (e.g. sewing, handicrafts), and talks about issues such as women's constitutional rights, violence against women and sexual and reproductive rights, some positive results have been obtained (Ckagnazaroff et al. 2006). There is a boost in women's self-esteem, they begin to learn more about their rights and to denounce domestic violence. Although this is an 'assistentialist' means to women's empowerment, it brings women together to discuss problems that they experience in similar ways, thus creating a space for women that could lead to consciousness-raising and collective action in the direction of 'liberating empowerment'.

\section{Liberating empowerment}

In mainstream development discourse, it seems clear that the empowerment of women is seen primarily as an instrument in poverty reduction and other development goals, even if women's empowerment makes an appearance in the Millennium Development Goals. For feminists of all walks, however, the empowerment of women is a goal in itself. Nevertheless, as noted earlier, what is conceptualised as empowerment, and how one should go about promoting it so that it can be a real 'liberating' force, are clearly debatable issues in feminist thinking.

A number of feminists sustain the notion, proposed by Kabeer (1999: 435), that empowerment is the process 'by which those who have been denied the ability to make strategic life choices acquire such an ability'. For Kabeer, this ability, in turn, rests on three distinct yet interrelated dimensions: (a) 'resources', pertaining to the existing pre-conditions; (b) 'agency', defined as 'power to', or as people's capacity to define and pursue their strategic choices despite possible opposition; and (c) 'achievements', the outcomes of one's exercise of their 'power to' capacity. Yet, Kabeer warns us that the 'conditions of choice' as well as the 'consequences of choice' are always shaped by context, and thus do not necessarily have 'transformatory significance', i.e. 'the extent to which the outcomes resulting from women exercising their choices have the potential to challenge and destabilise social inequalities or merely express or reproduce these inequalities' (Kabeer 1999: 461).

Although I agree with Kabeer that at the individual level, we may think of empowerment in those general terms, they do not allow us to discriminate between interventions aimed at enhancing women's resources, i.e. between those that simply sustain women in poverty or make a few women rich, and those that genuinely reduce inequality. They also do not make it possible for us to distinguish between uses of agency, whether for eradicating patriarchy or sustaining it, and thus, of thinking in terms of the transformatory significance of women's agency.

Perhaps because these issues are not clarified, a pared away version of Kabeer's model has been appropriated by the World Bank to support their efforts in transforming poor women into poor entrepreneurs. It is hardly surprising that in the process Kabeer's emphases are muted, or indeed lost altogether. Significantly, Kabeer (1999) strongly emphasises that in order to bring transformative changes, women's empowerment is dependent on collective solidarity and action.

In a later paper, Kabeer (2005) takes these considerations into greater account, qualifying the exercise of 'agency' in which feminists are interested: '...in transformative forms of agency that do not simply address immediate inequalities but are used to initiate longer-term processes of change in the structures of patriarchy' (2005: 16). In accordance with this perspective, therefore, we must think of ways of conceptualising empowerment towards women's liberation, beginning then, not just with individual women, but with women in the collective struggle for transformation. The strategy of consciousness-raising promotes the development of critical capacity for questioning and for the launching of collective action that can bring change. This is consonant with Stromquist's observations in regard to group participation and collective identity being mutually reinforcing: 'a person must first become 
part of some collective group to develop a collective identity; but, developing a sense of collective identity also leads women to mobilize' (2002: 32). This process involves the development of 'power with', a notion implicit in 'consciousness-raising' as a means of 'empowerment', and thus as a political strategy for change.

The notion that liberating empowerment implies a process of conscientisation, raises questions not only in regard to the sociopolitical dimensions of the phenomenon, but also to the psychological processes at play. It becomes important to understand 'how individuals come to understand the political dimensions of their personal problems and act accordingly' (Carr 2003: 9). As Batliwala rightly points out, the process of empowerment does not follow a linear course, instead, it unrolls in a spiral form, as the individuals involved act upon '...changing consciousness, identifying areas to target for change, planning strategies, acting for change, and analyzing action and outcomes, which leads into higher levels of consciousness and more finely honed and better executed strategies' (2002: 132)

Needless to say, this process does not unravel without conflict. To the contrary, as Romano (2002: 18) emphasises, empowerment is both a relational as well as a conflicting and contentious process. It is relational because it always involves 'links with other actors', and the power relations in which a given person is involved. Furthermore, the empowerment process is about a change in the structuring of these relations, in an individual as well as a group level, and thus cannot proceed without conflict. Indeed, conflict and coalition must be considered as part of the process of liberating empowerment, particularly when thinking in terms of 'women's empowerment'.

Ferguson (2004) suggests that if we consider these different sources of social oppression as intersecting each other rather than being 'merely additive', then it becomes impossible to separate them; one cannot detach gender identity from other bases of identity (and interests), such as class and race. This means that we cannot talk about women having common political interests, a notion that empties the women's movement of its social base. Ferguson also finds the suggestion that we should then assume a 'strategic essentialism' in thinking of women as a social group as questionable. She asks: 'can we assume women as a social group have common interests?' (2004: 2).
Yet, as Ferguson further observes, we can redefine interests by thinking in terms of 'formal interests' and 'content interests', along the lines proposed by Jonasdottir who takes a historical approach to this concept (in Ferguson 2004). Putting it simply, we may say that 'formal interests' would pertain to certain principles and interests that all members of a given broad social group agree upon, whereas 'content interests' refers to the specific ways in which they would apply to differently situated segments in the broader group. For example, Ferguson suggests that a formal common interest that women share is reproductive rights that are acknowledged and defended by the state in which they live; this neither implies that all women need or desire to exercise these rights, or that they have the same resources to do so, but that it would benefit all women to have access to reproductive choice. Ferguson further argues that these formal interests may be fostered on broader social justice coalition seeking 'democratic control over crucial material and non-material resources for other dispossessed social subjects, including men'. She thus concludes her argument by stating that there are two conditions for the emergence of a liberating empowerment process. The first such condition is the existence of an 'indigenous social movement' or one that 'involves some form of participatory democracy which gives it legitimacy to those it claims to speak for'. The second condition is the existence of means for negotiation of conflicts of interest between individuals and groups in the movement, particularly through coalitions of solidarity (Ferguson 2004: 8).

Clearly, then, differences and inequalities among women must be considered, for, some individuals may have power over others in a given group on the basis of class, race, etc, such that 'empowerment' may benefit some at the expense of others in the group. In such circumstances, therefore, liberating empowerment will only be possible if one approaches the issues from the standpoint of the women located in the most disadvantaged intersections. Indeed, this was precisely the strategy that was at play in the formulation of the Feminist Political Platform, presented by Brazilian feminists to presidential candidates in the 2002 elections, and, again, in the formulation of the basic principles for the 2004 and 2007 Action Plans for Women (Sardenberg 2005). 


\section{Conclusion: practising liberating empowerment in Latin America}

Magdalena León (2001) has argued that Latin American feminists have not been keen on discussing issues of power, because they (we) could only think of the question in terms of a 'power over' model. It was only after the Encuentro Feminista Latinoamericano y del Caribe (Latin American and Caribbean Feminist Encounters) was held in Mexico City in 1987, that they (we) began to recognise the possibility of other forms and models of power and thus consider processes of women's empowerment. But despite the absence of the term 'empowerment' in Latin American feminist discourse and a certain discomfort, if not mistrust, that continues to be associated with it, 'liberating empowerment' has been at work in the region since at least the late 1970s, when the first 'action and reflection' women's groups were created (Lavrin 1998). Building on a feminist critique of Freire's 'pedagogy of the oppressed' (1987), and negotiating coalitions among different movements, several of these groups developed into organisations offering special programmes geared to creating the conditions for the empowerment of women of all different standings and regions (see, for example, Thayer

\section{Notes}

1 This paper was presented at the Reclaiming Feminism, Gender and NeoLiberalism conference held at the Institute of Development Studies, Brighton, UK, 9-10 July 2007. A previous version of this paper was presented at the Pathways of Women's Empowerment Research Programme
2000). Despite differences and inequalities, strong coalitions have been articulated, within and between Latin American countries, in order to advocate and promote change in favour of women. This process of negotiating conflicts and articulating coalitions has also been deeply empowering in a liberating way to the women involved.

This approach to women's empowerment has certainly been of consequence to bringing institutional changes regarding gender relations, such as the important advancements registered in several Latin American countries within the last decade in the way of new legislation and 'machinery' to combat domestic violence (CLADEM/UNIFEM 2003). These gains are relevant to all women, regardless of their particular standing. In contrast, liberal empowerment approaches have only benefited a handful of women, and even then only in a very individualistic manner. It is no wonder Latin American feminists have not only been critical of these 'decaff' empowerment approaches, but continue to invest their efforts in programmes that promote 'consciousness-raising' and define the eradication of the immense social inequalities among women as a major goal of women's empowerment.

Consortium Inception Workshop, Luxor, Egypt in September 2006. I would like to thank Andrea Cornwall, Jasmine Gideon and Jenny Edwards for their help in shaping this version into a publishable article.

2 For a discussion of the different perspectives within Liberal Feminisms, see Baehr (2007). 


\section{References}

Allen, A. (2005) 'Feminist Perspectives on Power', in E. N. Zalta (ed.), Stanford Encyclopedia of Philosophy (Fall 2008 edition), http://plato.stanford.edu/ entries/feminist-power/\#Bib (accessed 1 October 2008)

Allen, A. (1999) The Power of Feminist Theory, Domination, Resistance, Solidarity, Boulder, CO: Westview Press

Alsop, R.; Bertelsen, M.F. and Holland, J. (2006) Empowerment in Practice: From Analysis to Implementation, Washington DC: World Bank

Baehr, A.R. (2007) 'Liberal Feminism', in E.N. Zalta (ed.) Stanford Encyclopedia of Philosophy (Fall 2008 edition), http://plato.stanford.edu/entries/ feminism-liberal/ (accessed 1 October 2008)

Batliwala, S. (2002) 'Grassroots Movements as Transnational Actors: Implications for Global Civil Society', Voluntas: International Journal of Voluntary and Nonprofit Organizations 13.4: 393-408

Batliwala, S. (1994) 'The Meaning of Women's Empowerment: New Concepts from Action', in G. Sen, A. Germain and L.C. Chen (eds), Population Policies Reconsidered: Health, Empowerment and Rights, Boston: Harvard University Press

Brock, K.; Cornwall, A. and Gaventa, J. (2001) Power, Knowledge and Political Spaces in the Framing of Poverty Policy, IDS Working Paper 143, Brighton: International Institute of Development

Bruera, S. and González, M. (2006) Las Mujeres y el Poder: Aprendiendo de las Prácticas Políticas de las Mujeres [Women and Power: Learning from Women's Political Praxis], Montevideo: Red de Educación Popular Entre Mujeres (REPEM)

Carr, E.S. (2003) 'Rethinking Empowerment Theory Using a Feminist Lens: The Importance of Process', Affilia 18.1, Spring: 8-20

Ckagnazaroff, I.; Cunha Melo, J. and Magrineli dos Reis, A. (2006) 'O Papel das ONG's em Processos de Empoderamento de Mulheres na Região Metropolitana de Belo Horizonte' ['The Role of NGOs in the Process of Women's Empowerment in the Belo Horizonte Metropolitan Region'] paper presented at the 'Fazendo Gênero 2006' Meetings, UFSC, Florianópolis, SC, www. fazendogenero7.ufsc.br/artigos/C/Ckagnazar off-Melo-Reis_38_B.pdf (accessed 1 October 2008)

CLADEM/UNIFEM (2003) Project on Domestic Violence, Latin American and Caribbean Committee for the Defense of Women's Rights (CLADEM) and United Nations Development
Fund for Women (UNIFEM), www.cladem.org/ english/regional/Violenciadegenero/Project/ (accessed 1 October 2008)

Cornwall, A.; Harrison, E. and Whitehead, A. (eds) (2007) Feminisms in Development: Contradictions, Contestations and Challenges, London: Zed Books de Lauretis, T. (1986) 'Introduction', in T. de Lauretis (ed.), Feminist Studies, Critical Studies, Bloomington, Indiana: Indiana University Press

Ferguson, A. (2004) 'Can Development Create Empowerment and Women's Liberation?', paper presented at the 2004 Center for Global Justice Workshop 'Alternatives to Globalization', www.globaljusticecenter.org/papers/ferguson.htm (accessed 1 October 2008)

Freire, Paulo (1987) Pedagogia do Oprimido [Pedagogy of the Oppressed], Rio de Janeiro: Paz e Terra, published originally in 1968

Kabeer, N. (2005) 'Gender Equality and Women's Empowerment: A Critical Analysis of the Third Millennium Development Goals', Gender and Development 13.1, March: 13-24

Kabeer, N. (1999) 'Resources, Agency, Achievements: Reflections on the Measurement of Women's Empowerment', Development and Change 30.3: 435-64

Kabeer, N. (1994) Reversed Realities, London: Verso Lavrin, A. (1998) 'International Feminisms: Latin American Alternatives', Gender and History 10.3: 519-34

León, M. (2001) 'El Empoderamiento de las Mujeres: Encuentro del Primer y Tercer Mundos en los Estudios de Género' ['Women's Empowerment: An Encounter of the First and Third World in Gender Studies'], La Ventana 13: 94-106

León, M. (ed.) (1997) Poder y Empoderamiento de las Mujeres [Power and Women's Empowerment], Bogotá: Coedición del Tercer Mundo Editores, Fondo de Documentación Mujer Y Genero de la Universidad Nacional de Colômbia

Mosedale, S. (2005) 'Policy Arena. Assessing Women's Empowerment: Towards a Conceptual Framework', Journal of International Development 17: 243-57

Oxaal, Z. and Baden, S. (1997) Gender and Empowerment: Definitions, Approaches and Implications for Policy, BRIDGE Report 40, www.bridge.ids.ac.uk/Reports/R40\%20Gen\%Emp \%20Policy\%202c.doc (accessed 1 October 2008)

Razavi, S. and Miller, C. (1995) From WID to GAD: Conceptual Shifts in the Women and Development Discourse, Geneva: United Nations Research Institute for Social Development (UNRISD) 
Romano, J.O. (2002) 'Empoderamento:

Recuperando a Questão do Poder no Combate à Pobreza' ['Empowerment: Recovering the Issue of Power in Combating Poverty'], in J. Romano and M. Antunes (orgs.), Empoderamento e Direitos no Combate à Pobreza [Empowerment and Rights in the Combat Against Poverty], Rio de Janeiro: ActionAid

Sardenberg, C. (2005) 'Pedagogias Feministas: Uma Introdução' ['Feminist Pedagogies: An Introduction'], in L.M. Bandeira (ed.), Violência Contra as Mulheres: A Experiência de Capacitação das DEAMs da Região Centro-Oeste [Violence Against Women: Experiences in Capacitation for Battered Women's Police Stations in the Mid-West Region], Brasilia, DF: AGENDE

Sen, G. and Grown, C. (1987) Development, Crisis, and Alternative Visions: Third World Women's

Perspectives, New York: Monthly Review Press

Sternbach, N.S.; Navarro-Aranguren, M.; Chuchryk, P. and Alvarez, S.E. (1992) 'Feminists in Latin America: From Bogotá to San Bernardo', Signs 17.2: 393-434
Stromquist, N.P. (2002) 'Education as a Means for Empowering Women', in J. Parpart, S. Rai and K. Staudt (eds), Rethinking Empowerment: Gender and Development in a Global/Local World, London: Routledge

Thayer, M. (2000) 'Traveling Feminisms: From Embodied Women to Gendered Citizenship', in M. Burawoy, J.A. Blum, S. George, Z. Gille, T. Gowan, L. Haney, M. Klawiter, S.H. Lopez, S. O'Riain and M. Thayer (eds), Global Ethnography: Forces, Connections, and Imaginations in a Postmodern World, Berkeley: University of California Press

Zabala, I. (2006) El Banco Mundial y su Influencia en las Mujeres y en las Relaciones de Género [The World Bank and its Influence on Women and Gender Relations], Cuadernos de Trabajo de Hegoa 41 [Hegoa Working Papers 41], October, Facultad de Ciencias Economicas (UPV/EHU) [Faculty of Economic Sciences], Bilbao: Lankopi, S.A. www.bantaba.ehu.es/obs/ocont/obsgen/doc/ bmgenero/ (accessed 1 October 2008) 